Final Report for Perlod: 01/1994 - 12/1998

Princtpal Investigator: Eisenberger, Peter M.

Orgamization: Princeton University

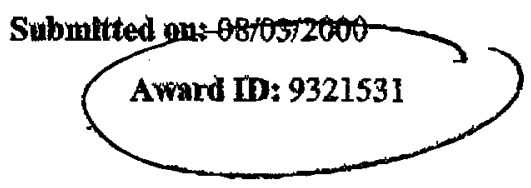

Workshops on Enhancing the Impact of University Research on Critical Technologies

Senior Persontel

\title{
Project Partidipants
}

Name: Eisenberger, Peter

Worked for more than 160 Hours: Yes

Contribution to Project:

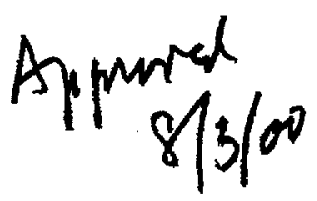

Name: Langer, James

Worked for more than 160 Honrs: Yes

Contribution to Project:

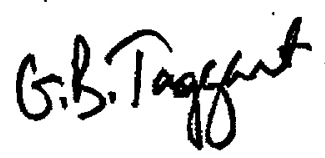

Post-doc

Graduate Student

Undergradmate Stadent

\section{Organizational Partmers}

\section{ETH Zurich}

ETH Zurich, the home institution of Dr. U.W. Suter who was one of the conference coondinators, provided some participant support.

Oniversity of California-Santa Barbara

The Materials Research Laboratory at UCSB concributed fumds to provide participant support ss well as non scientific staff assistance.

\section{Other Collaborntors ar Contaets}

Other coordinators of the MTP conference werc: A.K. Cheetham (UCSB, Materials Research Lab); Dr. A. Evans (UCSB); Dr. U.W. Suter (ETH Zurich); S. Yip (MM)

\section{Activities and Findings}

Project Activities and Findings:

This proposal was designed to initiate a series of workshops in which participants from universities, governnent and industry would look stratceically at selected areas of technological and societal importance. One of these workshops, dedicated to the discussion of how materials modeling can solve critical problems in industry, held at the Institute for Theoretical Physics, University of California Santa Barbara, Jamuary 7 through 11, 1996. "Modeling of Industrial Materials: Commecting Atomistic and Continurm Scales' was the first of a coordinated series of workshops, spanning over two years, being organized by a gromp of academic scientists at UCSB, MTT, and the Swiss Federal Institute of Technology Zurich (ETH). On the premise that materials research focused on technology also presents fundamentral scientific challenges, the Workshop sought to identify specific arcas of industrial needs and opportunities for materials modeling interpreted as theory and simulation across all the relevant length scales, and to stimulare meaningfil university-industry partnerships.

Funded primanily by a grant from the Mathematical and Physical Sciences Directorate of the National Science Foumdation, the Workshop was jointly sponsored by the Institute for Theoretical Physics and the Matetials Research Laboratory at UCSB, ETH Zurich, and the Center for Materials Science and Engineering at MT, with organizational support from the Industrial Linison Program and the Materials Processing 


\section{DISCLAIMER}

This report was prepared as an account of work sponsored by an agency of the United States Government. Neither the United States Government nor any agency thereof, nor any of their employees, make any warranty, express or implied, or assumes any legal liability or responsibility for the accuracy, completeness, or usefulness of any information, apparatus, product, or process disclosed, or represents that its use would not infringe privately owned rights. Reference herein to any specific commercial product, process, or service by trade name, trademark, manufacturer, or otherwise does not necessarily constitute or imply its endorsement, recommendation, or favoring by the United States Government or any agency thereof. The views and opinions of authors expressed herein do not necessarily state or reflect those of the United States Government or any agency thereof. 


\section{DISCLAIMER}

Portions of this document may be illegible in electronic image products. Images are produced from the best available original document. 
Center. Technical areas chosen for discussion were topics pertaining to the procossing and thermomechanical performance of composites, multilayers, polymeric and catalytic materials.

The Workshop was attended by 119 participants, the number limited by the facilities, with a distribution of $57 \%$ university, $30 \%$ industry, and $13 \%$ government labs. There were 31 participants representing fortign institutions.

In structuring the Program, conscious effiort was mado to follow through on the Workshop theme of developing an industrial perspective on materials modeling. After an overview by M. Ashby at the opening session, the issure of how industry can use materials modeling was adơressed directly in a plenary talk by J. Williams, with specific exarmples draWn from corrent technological requirements in developing aircraft engines. This was followed by a panel discussion of a wide fange of needs and opportunities in industry by scientists from the automotive and structural materials sectors, as well as the techmology and software vendors.

To stimulate discussions on the issue of university-industry collaboration, a list of questions was sent to the participants jist prior to the Wonkshop. These questions were the following:

For industrial participants:

What are specific examples of materials problems that your company - or your industry as a whole -- needs to solve?

In what way might numerical modeling be useful in the solution of these problems?

Are these problems so special that only in-house research is feasible, or do they have general features for which soluticns - perhaps in the form of computer codes - might have broader applicability?

What fundamental scientific issues might be involved?

What length scales -- atomic, mesoscopic, macroscopic - setm relevtm?

What kinds of skills and interactions will be needed in order to bring fundamental scientific advances to bear on the techological problems that arise in your industry?

Might your company be interested in participating in umiversity-government-industry collaborations aimed at solving these problems? Does it do so now?

What obstacles most be overcome in order for such collaborations to be formed and to function successfully?

For universiry and government participarits:

What are specific examples of advances in matcrials modeling that you think might be useful in indastry?

What are present limitations? Future prospects?

What fundamental scientific issues remain unresolved in the modeling problems with which you are familiar? What are the relevant length scales?

What obstacles do you perceive in establishing effective university-government-industry collaborations?

What kinds of industrial materials problems seem suitable for academic research? Which are unsuitable?

What gaps need to be bridged?

What is the role of government laboratories in these collaborations?

\section{Project Training and Development:}

At lesst partial answers to most of these questions, especially the more technical ones, emerged during the Workshop and are reported in the Proceedings. There was also considerable discussion of the policy-oriented questions. The paragraphs that follow are intended to convey some sense of the nature of those discussions. 
Final Report 9321531

Through these and subsequent deliberations among all the participants, a general sense of the intellectual basis and the practical constraints of university-industry cooperation is begining to enverge. Concentrating mostly on 'what to' rather than 'how to', the participants identified a number of hey areas where current advances in materials simulation and modeling can have significant impact on industrial research and development (see Part II for specifics). Since the basic scientific expertise resides to a large extent in the universities and government labs, collaboration with industry is clearly the next critical step it the rechinology transfer. However, establishing effective partnerships will require that each side be gemunely willing and able to acconmodate the particular constrainds and objectives of the other.

Defining shared values and formulating compatible objectives is generally not a straightforward process given the traditionally different measures of success (or relevance) adopted in each cormutinity. Consider the scenario where ons is asked to articulate the needs for modeling research. The industrial scientist is likely to cite the benefits of cost reduction, such as reducing the number of iterations in a product cycle or the cost of technology development. In contrast, the academic counterpart would be more inclined to emphasize fundanxental advances or innovation as the motivation. These two points of view need not neccssarily conffict, and indeed a greater window of opporturity would result if they can be realistically reconciled. Put in another way, what the Workshop intended to bridge was the gap between the knowledge-oriented approach traditionally fayored in academia and the problem-oriented approach that is necessary in inchustry. As seen by one momber of the panel discussion on industrial needs and opportunities, the intention of yniversity-indastry dialogue is not to dilute the scientific content of a research project, but to focus and integrate it for industrial impact.

Another panel discussion focused on existing programs and on-going initiatives promoting industrial applications of materials modeling. There appear to be only a few establishod programs and little operating experience that can provide guidance for the type of cooperative activities envisioned at the Workshop. A number of the industrial participants in both this panel and the one described previously reported successfil involvement in CRADA's and other consortia such as those sponsored by NST and the DOE Laboratories. They felt that their companies had more to gain from such involvement than they would lose by sharing technical information. In short, if important technical developments were occurring, they could not afford to be left out. Not all compamies represented at the Workshop shared this opinion, however; several participants stated or otherwise inplied that they had been sent to listen but not to share information. Moreover, there was a general sense of pessimism that the federal govermment would continue support for such activities.

Despite the lack of significant institutional support for research at the interface of academin and industry, there was much cnthusiasm amnong the participants for initiating some form of organized effort toxpard multi-instinutional cooperation. As one can sense from the various recommendations being put forwand in the Workshop Report, there is a spirit of'let's just do it ourselves' which points to the timeliness of the issues. Using the level of interest stimulated among the participants as an indication of success, the Workshop can claim that the first, step toward bringing about cooperation among university, industry, and government labs has been taken.

If the objective of assessing the scientific frontier in materials modeling across the length scales (in the specific topical areas addressed) has been achieved at this Workshop, it is quite apparent that the task of transferring the state-of-the-art technology to industry still lies ahead. Meaningfil progress is likely to result from a number of small-group efforts focusing on specific problems, and general programmatic support at the federal lovel, to be sure, can be amply justified on the basis of technological development and mampower training to meet national needs.

Further considerations of specific areas of opportumities along with implementation of some of the rocommendations resulting from this Workshop was taken op in the two following events in the coondinated series. Event Two was an extendod program entitled Quintitative Methods in Materials Research, held at the Institute for Theoretical Physics, UCSB, January - Jume 1997. A core of about I5 seientists were in residence for up to six months to engage in joimt studies on industrially relevant problems, including those identified at the Workshop, and to interact with industrial scientists invited for shorter visits. Coordinators of this event were A. K Cheetham, E. Kaxiras, J. S. Langer, and S. Yip. Event Three, a workshop linked to the two preceding programs, was scheduled for MTT, September 14-18, 1997. Organizers of this third event included R A Brown, J. Joamnopoulos, S. Suresh, and S. Yip. At each stage the intent was to brild on the experience from the preceding event, to engage industrial and academic scientists in constructive dialogies leading to specific collaborations, and to demonstrate the true benefits of maltiscale modeling to the entire materials community.

\section{Resesech Training:}

Outreach Activities:

The hastitute for Theoretical Physics kecps online records of its activities. While they are limited for this activity, what we have is available at hitp://www.titp.ucsb.edu/past/mat 97 ,hmml.

Iopragl Publications

Cheetham, Suter, Winmer, and Yip (Editors), "Modeling hindustrial Materials", Journal of Compuser-Aided Materials Design, p. 1, vol. 3, (1996). ) Published 
V. Bulatov, F. Abraham, L. Kubin, B. Devincre, and S. Yip, "Comecting Atomistic and Mesoscale Sitmulations of Crystal Plastecity", Nature, p. 669, vol. 391, (1998). ) Published

\section{Books or Other One-1ime Peblications}

URL(s):

\section{Web/Internet Sites}

hatp://www.itp.ucsb.edu/past/mat97.html http://oww.itp.ucsb.edu/solidification.html http://www.itp.ucsb.edw/fracture.html Description:

\section{Other Specific Products}

\section{Contributions within Discipline:}

\section{Contribations}

Only as detailed above.

Contributions to Other Discipltues:

Only as detailed above.

Contributions to Humas Resource Development:

Contributions to Science and Techmolopy Infrastructure:

This was one of the first projects that derailed on the ITP website. The Proceedings will be exfensively consulted by people in academia, industry, and government laboratories.

Beyond Science and Engineering:

\section{Catesories for which nothing is reportedi}

Activities and Findings: Any Research Training

Any Book

Any Product

Contributions: To Any Contributions to Human Resource Development

Contributions: Beyond Science or Engineering 